\title{
Investigation on Internal Factors of Non-Oil Export Obstacles Conceptual Model of Mirza Hassan
}

\author{
Majid Mahdinia* \\ Department of Management, Islamic Azad University of Babol, Iran
}

Received: June 25, 2018; Accepted: July 19, 2018; Published: July 26, 2018

*Corresponding author: Majid Mahdinia, Department of Management, Islamic Azad University of Babol, Iran. Tel: +989113000169; E-mail: majid. mahdinia1987@gmail.com

\begin{abstract}
Stable export development is one of the most necessary national destinations following economical field. The main concentration of future progress of country depends on export growth, especially in some goods that country has competitive advantage on them. Dr. Mirza Hassan one of the greatest professors of Payam Noor University was mentioned strategic conceptual model base on both political and economic point and has its important role for consistent progressing trend for country. By computing internal factors it has appeared that this model has obvious comparative advantage in both economic and industry. Goods in economy and small industries not only can provide needs of customers, but also can help people of country to make decision freely, meanwhile can helps to make export fundamental powerful. Exporting of these kinds of goods have fluctuated since recent decades and did not obey fixed process. This research has done base on introducing obstacles of non-oil export products with descriptive method. Statistical sample is 30 superior companies of Mazandaran. Questionnaire has evaluated by Likert spectrum and one sample T-test has used to recognize questionnaire. Findings of this research indicate that we face to difficult across exporting nonoil goods. This difficult has produced 11 subheadings that we tested them here.
\end{abstract}

Keywords: non-oil export; conceptual model; economy; Likert spectrum; T-test

\section{Introduction}

One of the most important strategies in country is progressing non-oil export which is concentrate on development plan of country. Base on theoretical topic, growing of global trade has specific role on country development. As regards to global trade trend has been encountered with decline in row material and the most reliable source for growing national product and increasing exchange revenue is exporting non-oil products; thereby paying attention to non-oil export is national entice.

Undoubtedly, sever relying on exporting oil is one of the basic characteristic of our country and rise and fall in this industry and its revenue make different type of basic difficulties in structural imbalance and lack of earning forecasting revenue of government not only effect on execution civil projects, but has negative effect on future of economy in Iran[4]. Though developing non-oil export and emancipation from single product economy is one of the most important target of Iran ,but existence of different kind of difficulties in producing structure and bureaucracy, high amount of oil price in first decade after revolution of Iran and happening unpredicted war make the first imagination less colorful; but after this era and entice of remaking the country, gradual decrease of oil price, unprecedented increasing of population, existence of giant geographical potentials, agriculture, education, history, increasing non-oil export and ultimately increasing exchange income of country enforced politicians to regard to non-oil export at the first and second development plan and make country released from single product which has a lot of fluctuations.

\section{Problem Expression}

Wide range of private sectors activities in different parts of economy in the country need progressing healthy competition, decline in production expense, expanding both quantity and quality of goods and services, increasing amount of export, motivating national economy and finally base of development is only promotion of enterprise with performing of free policy proportion with economy and it does not happened except of progressing and expanding private sectors; for making economy more practical, it is essential to pay attention to private sector at first and then regarding to motivate chamber of commerce. On the other hand, executing successful plans need to exact investigation on all theoretical aspects and evaluation of business enterprise performance for flourishing and progressing economy [6].

Privileged position base on product transition, proximity to middle Asia countries, producing and exporting of agriculture and sea products, having forest and natural sources and comparative advantage of Mazandaran province in exporting decorative stone and great facilities in engineering services and information technology, sea products such as Caviar, possibility to expand market share in producing plants and flowers are some of comparative advantages of Mazandaran province. Of course Mazandaran province is situated in north of Iran which is strategic according to long beaches and international sea lane and three port with the name of Noshahr, Behshahr and Ferydounkenar; also it was great transition pole because of high amount of loading per year and discharging export and import products [3].

At this moment Mazandarn province despite of having 
these opportunities, facilities and potential background in nonoil export field and privileged geographical situation, because of some impasses and problems such as lack of correct and comprehensive planning in export field and disconformity of organizations could not use its special position as appropriate as could [27]. Limitation of this research has regarded to investigation of non-oil export obstacles in Mazandarna province and also analyzing these obstacles with regarding to their priority, rate of exporter performance in elimination of existence obstacles, excavating optimum comments of responsible organizations such as chamber of commerce, mining and industry, business organization and exporters to identify better obstacles and executing to eliminate them base on excavated priority [5]. This research is trying to answer this fundamental question that "what are the worst challenges in exporting non-oil products? And what are the alternatives to solve these challenges?".

\section{Research Hypothesis}

- Non-oil export obey stable export trend.

- Bureaucracy is caused to developing non-oil export

- Non-oil exporters have export culture.

- There is money volume for non-oil export base on superior companies.

- Adaptation with need of consuming market has been done for non-oil export base on superior companies.

- There is official bases possibility to export non-oil goods for superior companies.

- Teaching has been done in optimum rate base on major superior companies.

- Good statistical analyzing has been done for exporting base on Teaching has been done in optimum rate base on superior companies.

- Transportation for export goods has good position base on superior companies.

- Harmony between activities of organizations and institutes in exporting non-oil goods in Mazandaran province is optimum base on superior companies.

- packaging for non-oil export is optimum base on superior companies.

\section{Theoretical Definition of Variable}

Consecutive changing of regulations totally confuses exporters. Sometimes exporting of dozens of merchandise items which some of them have over producing with a circular will be suspense or exporter cannot discharge products which are ready to export and all steps of exporting have done and it's ready to transit to frontier. While Because of number of ministries and organizations which are responsible for export, sometimes such misunderstanding happens between them which have negative effect on export.

Meanwhile long term process of bureaucracy make disturbance in sending export products at the time. Bureaucracy has different steps and the most important of them is necessity to catch license for some products which are variable during the year, of course it is possible to make rule that show forbidden products of next year at the end of this year. In most countries in the world, endowing export credits is paid by easy condition with cheap wage and it is one of the best ways for developing export and there are a lot of specific bank in this field to endow this credits to exporters. Many of exporters imagine that supplying products for international market is as same as supplying them for interior market, despite this kind of attitude is approximately wrong and number of export products because of their noncompliance quality and quantity with international consumption markets cannot be sold or it is not in amount that justify their post cost or marketing cost.

In recent world export is changing and each exporter who does not know regulation and technics of export and marketing in long term will have to get out of international markets. One of the most important problems of exporters is lack of access to needed statistic which is helpful for their development and research group.

\section{Research Literacy}

Progress and degradation of countries is not just because of army, weapon, political glory or even their power, although in centuries before these factors were part of the most important national foundation of dynasty and governments just were popular by their military power, but today for stability measurement or weakness of their independence standard is economic condition [1].

Iran was one of the greatest country both before Islam and after that and Iranian businessmen in both periods were popular and had vast amount of trade with Chinese, Indian, Byzantine and Roman; thereby these trades had different condition during this long period. Some times because of powerful government had glory and sometimes because of riots and anarchy had decadence [29].

\section{Iranian Trade History have Two Parts}

The first part is geographical position of Iran and secondary is business of Iran. About geographical position of Iran should be known that this country from the past time was highway between Asia and Mediterranean Sea and Asia Sea, so most of commuting passed this way. Since 1931 which central department of commerce was established by law and international trade was exclusively duty of government, many of promotions were determined till between 1939 and 1941 export rate during a year was 200 million Rials more than import but with starting of second world war and occupation of country by Allied forces, international trade had unfortunate disturbance and ceased all developing programs. After finishing war and changing condition, special policy legislated to support interior industry and production. After revolution of Iran in 1978 policies and regulations of Iran revised to decline external dependency, but continuing existence problems in 1979 and announcing economical restriction against 
of Iran by America and some of European countries in 1980 and the most important war between Iran and Iraq and declination of export rate specially in oil caused to limit Iran exchange source. On the other hand because of inability of Iran to buy directly and necessity to buy by mediators, purchase price of import goods were increased [7].

In 1982 with approving foreign trade as governmental mission and changing geopolitical condition of Iran due to other countries import and export have gotten steep increased until in 1996 its amount reach to more than 29373409 million Rials which 23938419 million Rials [81.5\%] was for import and 5434990 million Rials [18.5\%] was for export.

There are many researches about export which indicates importance and efficiency of it in economical field. Investigation on researches in this field can help to find role and effect of variable and export; so here study in this field is mentioned [2].

Goldstein and Khan in manuscript have mentioned to export supply and demand function between eight countries include Germany, Italy, Japan, England, Belgium, France and united states for time periods between[ 1955-1970]. Results indicated all price elasticity in demand function of export [except Japan] is negative and income elasticity is positive for all of them. Also base on prediction export coefficient in supply function has positive sign and about seven countries [except Japan] statistically are significant [8].

Mervar has worked on stimulating demand function of import and export in xorvatiya. This research had done base on ordinal least square [OLS] monthly statistic from january1990 to December 1993. Author in this research had used real exchange rate instead of relative price. Results indicated positive significant relationship between real exchange rate and export value [11].

Chawang had investigated determinative ingredient of import and export demand in his dissertation in Thailand by Johanson- Julius method and annual statistic of Thailand during [1970-1999]. Author had resulted demanding import in long term is more elastic than price and income and on the other hand in export demand function cannot comment, but its income elasticity is higher [26].

Sharma in manuscript had investigated on determinant factors of export function. This manuscript has been done by annual statistic of [1970-1998] with simultaneous equations. Results of his study indicate that increasing price has contrary effect on export function of India and export supply has positive relation with amount of export and foreigner direct investment has not effect on export function statistically, despite this variable coefficient is positive [13].

Seyoum had worked on trade function of America and development countries with panel data in [1965-1990] in his research. Author have gotten this result that total export function of America has significant and positive effect on beneficiary sectors and producing group; on the other hand, necessity to know relations between receiving governmental credits can help to increasing export function of America because this case can have great effect on export [16].

Wilkinson and Brouthers in a paper mentioned to investigation on alternatives to increasing trade and export function of United States. Their study indicated that after controlling amount of trade, all effective factors on export have positive effect on export function thereby cognition of effective factors of export id really essential [15].

Nur et al in research regarded to estimate demand function of Bangladesh export by time series [1973-2004]. Authors by using collaborative method of Parasite and Granger has achieved long term relation between Bangladesh and each five superior trade countries and expressed it that income elasticity of export for France, Germany and United States is positive and for England, and Belgium id positive but without elasticity. Price elasticity of export although is negative for all five countries except of France [12].

Law et al had worked on relation between economic freedom and direct investment. Authors of this worked on this research by using generalized moment method [GMM] and with panel data of 85 countries during [1976-2004]. Results of mentioned study indicated that direct foreigner investment has depends on its effect on export [10].

Prasanna worked on effect of direct foreigner investment on export function of India during [1991-2007]. This author in his study by using panel data method got this result that direct foreigner investment have positive effect on export function of India and suggested to politicians more work on attracting direct foreigner investment and evaluate alternatives to achieve this aim [13].

Agriculture faculty of university of Colorado has researched for nutrition companies and achieve to this result that most of export obstacles depends on failure to have proportion contact with importers and purchasers with 17.1 percent and time limitation for developing market about 16 percent and also lack of knowing special market with 10 percent are the worst obstacles across export.

University of Canada expressed in research export obstacle for small and middle companies are management, marketing barriers, lack of governmental aid and financial obstacle; in this research 53 questions were designed and 1000 companies were chosen [ " 1 " for disagree and "7" for agree]. Five groups had chosen by title literacy and five variables were removed because of lack of correlation and also for low developing countries obstacles were management problems, operational problems and lack of governmental aid.

vilxson and et al [2006] in research with title of " transaction promotion in small companies" understand that export promotion has indirect effect on export function as a process in steads of direct effect on export function of companies [15]. Leonid et al in study " determination of marketing strategy for export function" by analyzing 36 case study have classified effective factors on export in five group which are include: 1 . Management factors [experience of person, perception and behavioral characteristic 
of participants] 2. Organization factors [factors relates to operational sources and organization aims] 3. Environmental factors [environmental factors which have cause to irritation in exporter company] 4.Targeting export market [knowing and choosing international destination market] and 5. Mix variable of marketing [price, promotion, product and place] [31].

Singer in study about " role of export promotion in export management" claimed that promotion policies are unusual function in international trades which its target is helping to progressing and welfare of society and tempt factors with aim to motivate companies have used for exporting companies. These programs are divided in two groups for regarding people to play role: group one is programs which inform companies and group two provides opportunity for companies to learn export actively [18].

Spencer in 1988 expressed establishers of trade strategic policy at the first of 1980s codified trade strategy during two steps: a. choosing strategic industries b. targeting chosen industries by trade strategic tools. It seems to him that the most important factor for choosing strategic industry is profitability which means industries are more profitability has high amount of priority and supporting them fortify motivation of producing and export and have permanent production and export. He for choosing industries in developing countries for supporting relevant comparative appeared factors [RCA] and knowledge introduce amount of investment in developing and research $[R \& D]$ as a scale.

Also Harb in study expressed that oil income has not long term effect on economy and also can not criticize it for its bad function in economy, too [17].

Rajapattirana in case study understood that negative effects of import limitations on export productions are significant Specifically import limitations has contrary effect on availability to import, these products almost use in producing internal goods; furthermore, totally it is appeared that import limitations has significant vice versa effects on export function in developing countries. This study had done base on Liberal exchange policy which lead by positive and negative function, however some studies have find positive effects of companies between Liberal exchange and export function; of course some other studies were find low amount of case study support Liberal exchange contacts and export functions [25].

Promotion is one of the best tools for developing and progress which is applied by many countries since 1970 . Role of export in economic progress and relation between these two issues were studied by a lot of scientific and experimental researchers in economic exchange and in the field of developing.

Base on Abu Smith [2005] regarded issue as role of export is such as determination factor for developing economy and it back to Adam Smith and Ricardo, the establishers of classic school of economy [32]. Also most of previous studies have this claim that growing export cause to total advancement of economy and due to this making relationship between these two variables and developing those exports which is cause to distribute economic growth [5].

\section{Methodology}

Method of research is surveying and in this way researcher is looking for describing variable. On the other hand researcher attempts in this survey to report everything as it is without any inference or mental conclusion and getting objective results from reality. Specifically in descriptive research, researcher not only entices to detect and explain correlation relations and maybe test hypothesis or predict events, but also the more regard to describe and report opportunities and events based on information which are exactly descriptive [33].

Descriptive methods are the ways which aim to describe conditions or phenomena. These descriptions wield to recognize or help for making decision process. Descriptive methods have different types. First we use fundamental search for investigating total thesis, abstracts and basic for getting reliability of questionnaire in this research used from professors guidance and of course had special consultant with pundits and totally shape and content ambiguities were denied which id indicate reliability of questionnaire.

Reliability coefficient of research has calculated according to Cranach's Alpha in export trade market of Mazandaran province. For reliability of questionnaire in this research, introductory performance has done for $30 \%$ of samples and $0 / 74$ has caught which means questionnaire has interior stability and monotonous. [Table 1]

Table1: Reliability criterion by cronbach Alpha

\begin{tabular}{|c|c|}
\hline Cranach's Alpha & $\begin{array}{c}\text { Cronbach's Alpha Based on } \\
\text { Standardized Items }\end{array}$ \\
\hline $0 / 477$ & $0 / 477$ \\
\hline
\end{tabular}

For performing below research can use from different kind of models for choosing evaluating index which base on past studying one of the most complete of them is introduced by Mirza Hassan in 2008 under the name of " export and import management" Payam Noor publication [Mirza Hassan, 2008].

In this model with regarding to past studies obstacles of non-oil export are divided into two kind of internal and external factors that internal factors include eleven index below:

- Failure to obey stable export trend

- Bureaucracy

- Lack of export culture

- Low amount of money volume for continuing export activity

- Lack of adaption of product quality with needs of consuming market

- Smuggling of export products

- Disregarding to teaching export cases

- Statistical problems for analyzing export 
- Lack of harmony between organization and institution activity

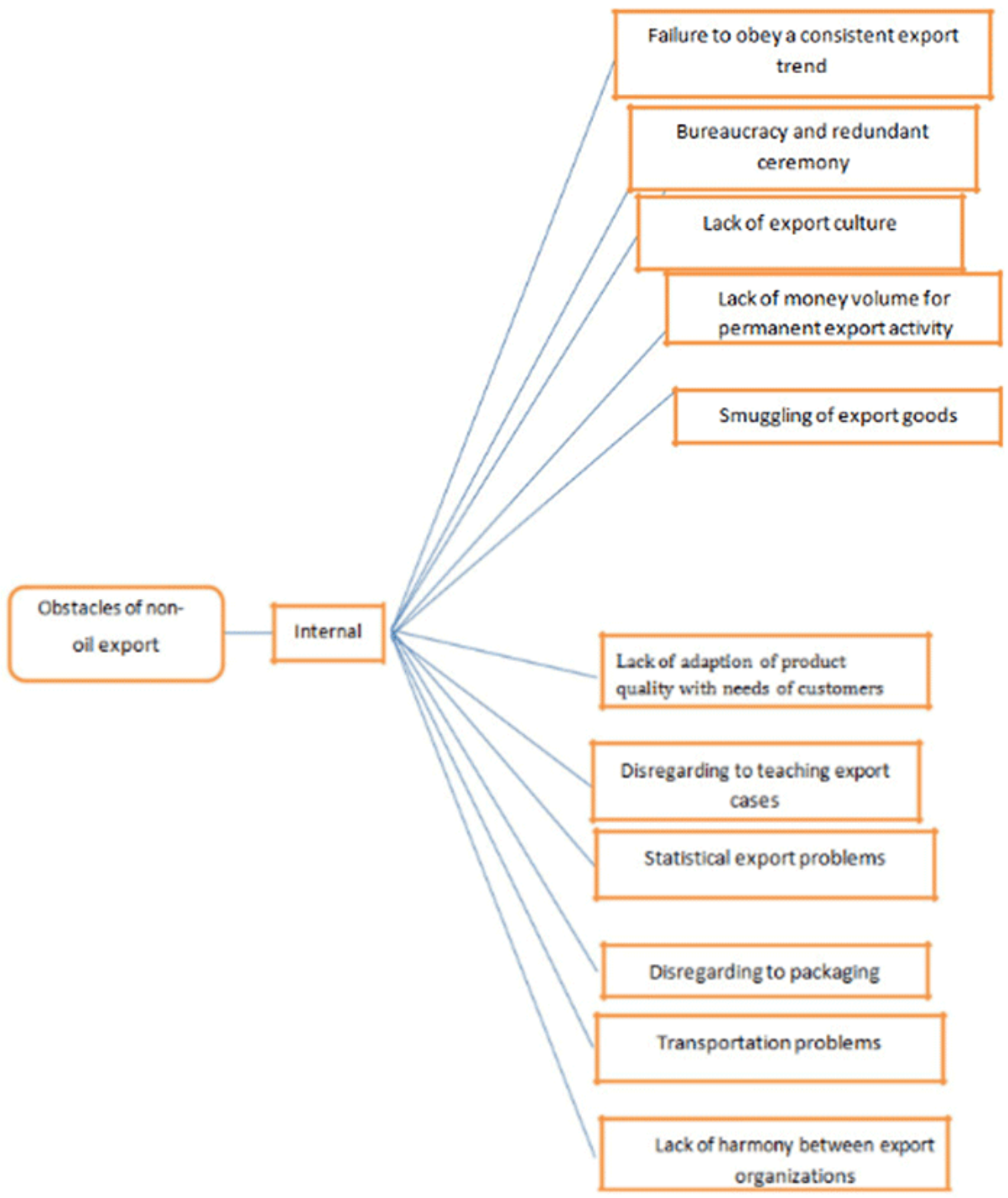

Table 2: Obstacles of non-oil export (Mirza Hassan, 2008)

Hypothesis number 1: Non-oil export obey stable export trend. This hypothesis includes three questions and base on total items which constitute it, average and standard deviation are indicated. [Table 3]
Average of this factor is 2.91 and standard deviation is 0.65 . [Table 4]

Table3: Statistical data of stable export trend

\begin{tabular}{|c|c|c|c|c|}
\hline Standard Average Deviation & Standard Deviation & Average & Number & \\
\hline 0.03374 & 0.65779 & 2.9147 & 70 & $\begin{array}{c}\text { Non-oil export stable } \\
\text { trend }\end{array}$ \\
\hline
\end{tabular}



Conceptual Model of Mirza Hassan

\begin{tabular}{|c|c|c|c|c|c|c|c|}
\hline \multicolumn{2}{|c|}{$95 \%$ significant rate } & \multirow{2}{*}{ Average Difference } & \multirow{2}{*}{ Sig. } & \multirow{2}{*}{ Freedom Rate } & \multirow{2}{*}{ table t $5 / 50$} & \multirow{2}{*}{ t caught } & \\
\hline The most & The least & & & & & & \\
\hline-5.0190 & -5.1517 & -5.08534 & 5055 & 29 & 2.706 & -2.829 & $\begin{array}{c}\text { Non-oil export } \\
\text { stable trend }\end{array}$ \\
\hline
\end{tabular}

\section{Interpretation}

As table shows $\mathrm{t}$ has caught [-2.829] and it is more than $\mathrm{t}$ of table; so, significance even with the gauge of $99 \%$ [1 percent failure] is the possibility for accuracy, it means this kind of difference is not accidently. The concept of that is difference of non-oil export fixed policy from Likert average is significant. Negative sign of average difference shows that real average is less than Likert average; indeed it can be mentioned that lack of nonoil Non-oil export stable trend is one of the obstacles for superior companies.
Hypothesis number 2: There is bureaucracy and redundant ceremony for non-oil exporter of Mazandaran province. This hypothesis includes three questions and base on total items which constitute it, average and standard deviation are indicated. [Table 5]

Average of this factor is 2.04 and standard deviation is 0.62 . [Table 6]

\begin{tabular}{|c|c|c|c|c|}
\hline Table 5: Statistical data of Bureaucracy and redundant ceremony \\
\hline Standard average deviation & Standard deviation & average & number & \\
\hline 0.11495 & 0.62962 & 2.044 & 70 & $\begin{array}{c}\text { Bureaucracy and redundant } \\
\text { ceremony }\end{array}$ \\
\hline
\end{tabular}

Table 6: T-table for Bureaucracy and redundant ceremony

\begin{tabular}{|c|c|c|c|c|c|c|c|}
\hline \multicolumn{2}{|c|}{$95 \%$ significant rate } & \multirow{2}{*}{$\begin{array}{c}\text { Average } \\
\text { Difference }\end{array}$} & \multirow{2}{*}{ Sig. } & \multirow{2}{*}{$\begin{array}{l}\text { Freedom } \\
\text { Rate }\end{array}$} & \multirow{2}{*}{$\begin{array}{c}\text { table t } \\
5 / 50\end{array}$} & \multirow{2}{*}{ t caught } & \\
\hline The most & The least & & & & & & \\
\hline-1.2795 & -0.8093 & -0.9666 & 5055 & 29 & 2.760 & -9.086 & $\begin{array}{l}\text { Bureaucracy and } \\
\text { redundant ceremony }\end{array}$ \\
\hline
\end{tabular}

\section{Interpretation}

As table shows t has caught -9.086] and it is more than $t$ of table; so, significance even with the gauge of 99\% [1 percent failure] is the possibility for accuracy, it

Means this kind of difference is not accidently. The concept of that is difference of Bureaucracy and redundant ceremony from Likert average is significant. Negative sign of average difference shows that real average is less than Likert average; indeed it can be mentioned that Bureaucracy and redundant ceremony is one of the obstacles for superior companies.

Hypothesis number 3: There is low amount of export culture in Mazandaran province. This hypothesis includes three questions and base on total items which constitute it, average and standard deviation are indicated. [Table 7]

Average of this factor is 2.78 and standard deviation is 0.59 . [Table 8]

Table 7: Statistical data of Export culture

\begin{tabular}{|c|c|c|c|c|}
\hline Standard average deviation & Standard deviation & average & number & Export culture \\
\hline 0.19343 & 0.59470 & 2.7889 & 70 & .
\end{tabular}

Table 8: T-table for Export culture

\begin{tabular}{|c|c|c|c|c|c|c|c|}
\hline \multicolumn{2}{|c|}{$95 \%$ significant rate } & \multirow{2}{*}{$\begin{array}{c}\text { Average } \\
\text { Difference }\end{array}$} & \multirow{2}{*}{ Sig. } & \multirow{2}{*}{ Freedom Rate } & \multirow{2}{*}{ table t $5 / 50$} & \multirow{2}{*}{ t caught } & \\
\hline The most & The least & & & & & & \\
\hline-0.4845 & -0.1933 & -0.2111 & 5055 & 29 & 2.760 & -4.078 & $\begin{array}{l}\text { Export } \\
\text { culture }\end{array}$ \\
\hline
\end{tabular}

\section{Interpretation}

As table shows t has caught -4.078] and it is more than $t$ of table; so, significance even with the gauge of 99\% [1 percent failure] is the possibility for accuracy, it means this kind of difference is not accidently. The concept of that is difference of
Export culture from Likert average is significant. Negative sign of average difference shows that real average is less than Likert average; indeed it can be mentioned that low amount of export culture is one of the obstacles for superior companies.

Hypothesis number 4: There is low amount of money for non-oil exporter of Mazandaran province. This hypothesis 

Conceptual Model of Mirza Hassan

includes three questions and base on total items which constitute it, average and standard deviation are indicated. [Table 9]
Average of this factor is 2.08 and standard deviation is 0.62 . [Table 10]

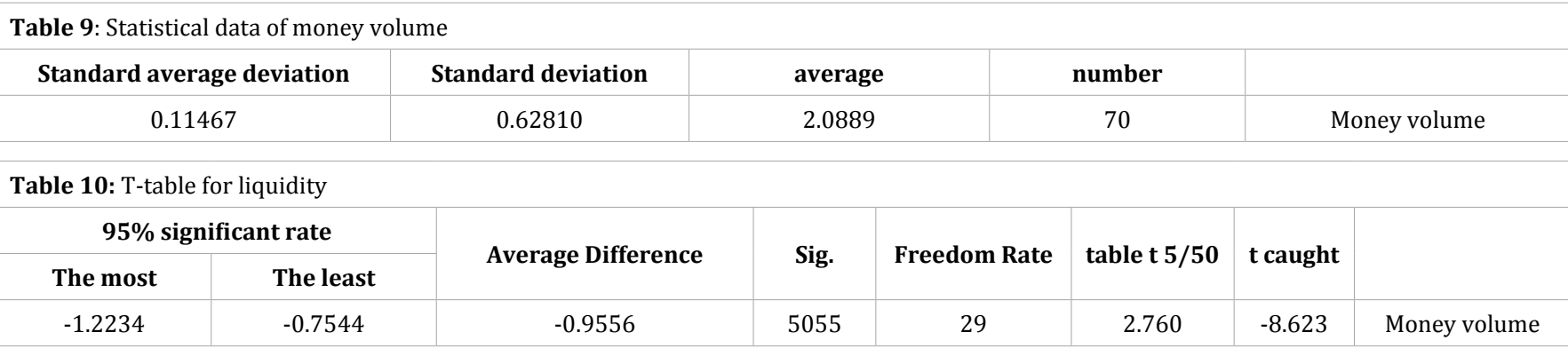

\section{Interpretation}

As table shows t has caught [-8.623] and it is more than $t$ of table; so, significance even with the gauge of $99 \%$ [ 1 percent failure] is the possibility for accuracy, it means this kind of difference is not accidently. The concept of that is difference of liquidity from Likert average is significant. Negative sign of average difference shows that real average is less than Likert average; indeed it can be mentioned that low amount of liquidity

Hypothesis number 5: There is lack of harmony between goods quality and consuming market for non-oil exporter of Mazandaran province. This hypothesis includes three questions and base on total items which constitute it, average and standard deviation are indicated. [Table 11]

Average of this factor is 2.07 and standard deviation is 0.71 . [Table 12] is one of the obstacles for superior companies.

Table 11: Statistical data of lack of coordination between products quality and consuming market

\begin{tabular}{|c|c|c|c|c|}
\hline Standard average deviation & Standard deviation & average & number & Lack of harmony between products \\
quality and consuming market
\end{tabular}

Table12: T-table for lack of coordination between products quality and consuming market

$95 \%$ significant rate

\begin{tabular}{|c|c|c|c|c|c|c|}
\hline The most & The least & Average Difference & Sig. & Freedom rate & table t 5/50 & t caught \\
\hline-1.1447 & -0.7106 & -0.9222 & 5055 & 29 & $2.76 \quad \begin{array}{c}-8.258 \\
\text { lack of harmony between } \\
\text { products quality and } \\
\text { consuming market }\end{array}$ \\
\hline
\end{tabular}

\section{Interpretation}

As table shows $t$ has caught [-8.258] and it is more than $t$ of table; so, significance even with the gauge of 99\% [1 percent failure] is the possibility for accuracy, it means this kind of difference is not accidently. The concept of that is difference of lack of coordination between products quality and consuming market from Likert average is significant. Negative sign of average difference shows that real average is less than Likert average; indeed it can be mentioned that low amount of lack of harmony between products quality and consuming market is one of the obstacles for superior companies.

Hypothesis number 6: There is smuggling export products for non-oil exporter of Mazandaran province. This hypothesis includes three questions and base on total items which constitute it, average and standard deviation are indicated. [Table 13]

Average of this factor is 2.36 and standard deviation is 0.56 . [Table 14]

Table13: Statistical data of smuggling export products

\begin{tabular}{|c|c|c|c|c|}
\hline Table13: Statistical data of smuggling export products & average & number \\
\hline Standard average deviation & Standard deviation & 2.3667 & 70 & smuggling export products \\
\hline 0.18799 & 0.56769 & & 70 \\
\hline
\end{tabular}

Table14: T-table for smuggling export products $\mathbf{9 5 \%}$ significant rate

\begin{tabular}{|c|c|c|c|c|c|c|c|}
\hline \multicolumn{2}{|c|}{$95 \%$ significant rate } & \multirow[b]{2}{*}{ Average Difference } & \multirow[b]{2}{*}{ Sig. } & \multirow[b]{2}{*}{ Freedom rate } & \multirow[b]{2}{*}{$\begin{array}{c}\text { table } t \\
5 / 50\end{array}$} & \multirow[b]{2}{*}{ t caught } & \\
\hline The most & The least & & & & & & \\
\hline-0.8511 & -0.0178 & -06333 & 5055 & 29 & 2.760 & -5.591 & $\begin{array}{l}\text { Smuggling exports } \\
\text { products }\end{array}$ \\
\hline
\end{tabular}




\section{Interpretation}

As table shows $\mathrm{t}$ has caught [-5.591] and it is more than $\mathrm{t}$ of table; so, significance even with the gauge of $99 \%$ [ 1 percent failure] is the possibility for accuracy, it means this kind of difference is not accidently. The concept of that is difference of smuggling export products from Likert average is significant. Negative sign of average difference shows that real average is less than Likert average; indeed it can be mentioned that smuggling export products is one of the obstacles for superior companies.
Hypothesis number 7: There is optimum education opportunity for non-oil exporter of Mazandaran province. This hypothesis includes three questions and base on total items which constitute it, average and standard deviation are indicated. [Table 15]

Average of this factor is 2.73 and standard deviation is 0.75 . [Table 16]

Table15: Statistical data of optimum teaching opportunity

\begin{tabular}{|c|c|c|c|c|}
\hline Standard average deviation & Standard deviation & average & number & \\
\hline 0.13758 & 0.75506 & 2.7333 & 70 & $\begin{array}{c}\text { Optimum teaching } \\
\text { opportunity }\end{array}$ \\
\hline
\end{tabular}

Table 16: T-table for optimum teaching opportunity

$\mathbf{9 5 \%}$ significant rate

\begin{tabular}{|c|c|c|c|c|c|c|c|}
\hline \multicolumn{9}{|c|}{$\mathbf{9 5 \%}$ significant rate } & \multicolumn{1}{|c|}{$\begin{array}{l}\text { Average } \\
\text { The most }\end{array}$} & The least & $\begin{array}{c}\text { Sig. } \\
\text { Difference }\end{array}$ & Freedom rate & table t 5/50 & t caught & \\
\hline-0.4153 & -.0514 & -0.2667 & 5055 & 29 & 2.760 & -5.320 & $\begin{array}{c}\text { Optimum teaching } \\
\text { opportunity }\end{array}$ \\
\hline
\end{tabular}

\section{Interpretation}

As table shows $\mathrm{t}$ has caught [-5.320] and it is more than $\mathrm{t}$ of table; so, significance even with the gauge of $99 \%$ [1 percent failure] is the possibility for accuracy, it means this kind of difference is not accidently. The concept of that is difference of optimum education opportunity from Likert average is significant. Negative sign of average difference shows that real average is less than Likert average; indeed it can be mentioned that minimum education opportunity is one of the obstacles for superior companies.
Hypothesis number 8: There is lack of statistical analyzing problems for non-oil exporter of Mazandaran province. This hypothesis includes three questions and base on total items which constitute it, average and standard deviation are indicated. [Table 17]

Average of this factor is 2.54 and standard deviation is 0.8 . [Table 18]

\begin{tabular}{|c|c|c|c|c|}
\hline Table 17: Statistical data of lack of statistical analyzing & \multicolumn{2}{|l|}{} \\
\hline $\begin{array}{c}\text { Standard average } \\
\text { deviation }\end{array}$ & Standard deviation & average & number & Statistical analyzing \\
problems
\end{tabular}

Table 18: T-table for lack of statistical analyzing $\mathbf{9 5 \%}$ significant rate

\begin{tabular}{|c|c|c|c|c|c|c|c|}
\hline The most & The least & Average Difference & Sig. & Freedom rate & table t $5 / 50$ & t caught & \\
\hline-0.6453 & -0.2436 & -0.4556 & 5055 & 29 & 2.760 & -7.099 & $\begin{array}{l}\text { Statistical } \\
\text { analyzing } \\
\text { problems }\end{array}$ \\
\hline
\end{tabular}

\section{Interpretation}

As table shows $t$ has caught [-7.099] and it is more than $t$ of table; so, significance even with the gauge of $99 \%$ [1 percent failure] is the possibility for accuracy, it means this kind of difference is not accidently. The concept of that is difference of lack of statistical analyzing from Likert average is significant. Negative sign of average difference shows that real average is less than Likert average; indeed it can be mentioned that lack of statistical analyzing is one of the obstacles for superior companies.

Hypothesis number 9: There is transition problem for non-oil exporter of Mazandaran province. This hypothesis includes three questions and based on total items which constitute it, average and standard deviation are indicated. [Table 19]

Average of this factor is 2.13 and standard deviation is 0.77 . [Table 20] 


\begin{tabular}{|c|c|c|c|c|c|c|c|}
\hline \multicolumn{2}{|c|}{ Standard average deviation } & Standard deviation & average & \multicolumn{2}{|c|}{ number } & & \\
\hline \multicolumn{2}{|c|}{0.14079} & 0.77113 & 2.1333 & \multicolumn{2}{|c|}{70} & \multicolumn{2}{|c|}{ transportation problem } \\
\hline \multicolumn{8}{|c|}{ Table 20: T-table for transportation problem } \\
\hline \multicolumn{8}{|c|}{$95 \%$ significant rate } \\
\hline The most & The least & Average Difference & Sig. & Freedom rate & table t $5 / 50$ & t caught & \\
\hline-1.1213 & -0.6456 & -0.8667 & 5055 & 29 & 2.760 & -8.05 & $\begin{array}{c}\text { Transportation } \\
\text { problem }\end{array}$ \\
\hline
\end{tabular}

\section{Interpretation}

As table shows $t$ has caught [-8.05] and it is more than $t$ of table; so, significance even with the gauge of 99\% [1 percent failure] is the possibility for accuracy, it means this kind of difference is not accidently. The concept of that is difference of transition problem from Likert average is significant. Negative sign of average difference shows that real average is less than Likert average; indeed it can be mentioned that transition problem is one of the obstacles for superior companies.
Hypothesis number 10: There is coordination between organization and institute of Mazandaran province is satisfactory for non-oil exporter of Mazandaran province. This hypothesis includes three questions and base on total items which constitute it, average and standard deviation are indicated. [Table 21]

Average of this factor is 2.83 and standard deviation is 0.77 . [Table 22]

Table 21: Statistical data of harmony between organization and institute

Standard average deviation

0.14183
Standard deviation

0.77682

\begin{tabular}{|c|c|}
\hline average & number \\
\hline 2.8333 & 70 \\
\end{tabular}

Coordination between organization and institute

Table 22: T-table for harmony between organization and institute

\section{$95 \%$ significant rate}

\begin{tabular}{|c|c|c|c|c|c|c|c|}
\hline \multicolumn{2}{|c|}{$\mathbf{9 5 \%}$ significant rate } & \multirow[b]{2}{*}{ Average Difference } & \multirow[b]{2}{*}{ Sig. } & \multirow[b]{2}{*}{ Freedom rate } & \multirow[b]{2}{*}{$\begin{array}{c}\text { table t } \\
5 / 50\end{array}$} & \multirow[b]{2}{*}{ t caught } & \\
\hline The most & The least & & & & & & \\
\hline-0.1234 & -0.0433 & -0.1667 & 5055 & 29 & 2.760 & -5.876 & $\begin{array}{c}\text { Harmony between } \\
\text { organization and } \\
\text { institute }\end{array}$ \\
\hline
\end{tabular}

\section{Interpretation}

As table shows $\mathrm{t}$ has caught [-5.876] and it is more than $\mathrm{t}$ of table; so, significance even with the gauge of $99 \%$ [ 1 percent failure] is the possibility for accuracy, it means this kind of difference is not accidently. The concept of that is difference of coordination between organization and institute from Likert average is significant. Negative sign of average difference shows that real average is less than Likert average; indeed it can be mentioned that coordination between organization and institute is one of the obstacles for superior companies.
Hypothesis number 10: There is optimum arena cooperation for non-oil exporter of Mazandaran province. This hypothesis includes three questions and base on total items which constitute it, average and standard deviation are indicated. [Table 23]

Average of this factor is 2.71 and standard deviation is 0.87 . [Table 24]

Table 23: Statistical data of arena cooperation

\begin{tabular}{|c|c|c|c|c|}
\hline Standard average deviation & Standard deviation & average & number & \\
\hline 0.16041 & 0.87858 & 2.7111 & 70 & arena cooperation \\
\hline
\end{tabular}

Table 24: T-table for arena cooperation

\section{5\% significant rate}

\begin{tabular}{|c|c|c|c|c|c|c|c|}
\hline The most & The least & Average Difference & Sig. & Freedom rate & table t 5/50 & t caught & \\
\hline-0.3392 & -0.1830 & -0.2889 & 5055 & 29 & 2.760 & -4.443 & arena cooperation \\
\hline
\end{tabular}




\section{Interpretation}

As table shows $\mathrm{t}$ has caught [-4.443] and it is more than $\mathrm{t}$ of table; so, significance even with the gauge of 99\% [1 percent failure] is the possibility for accuracy, it means this kind of difference is not accidently. The concept of that is difference of regional cooperation from Likert average is significant. Negative sign of average difference shows that real average is less than Likert average; indeed it can be mentioned that lack of regional cooperation is one of the obstacles for superior companies.

\section{Conclusion}

Scientific investigations approved that economic growth of countries have direct relation with their export growth. International trade and export not only stranger with Iran during the time, but also because of laying Iran in passage of east and west and also being Iran as center of civilization in the past and now has substantial role in economy.

Non-oil export of country mostly includes traditional products and exporter of industrial products almost export in limit boundary, their financial budget for marketing or achieving latest news or even educate in the latest science to have effective presence in international market is restricted. Furthermore, decline in oil export income and its fluctuates, increasing of country population, decreasing of oil income purchasing power and more important of others being exhaustible oil source; have learnt politicians and strategists that developing non-oil export and taking out country from single product economy. Frustration of most countries which used replaced import strategy and this reality that new industrialized country of Asia which are mainly by industrialized by export developing strategy and could have permanent growth in international market are also effective in choosing developing export strategy of country.

Unfortunately, dependency of country to oil export income in recent decades caused that economic and business structure formed with export of oil and supplying shortage needs by import and in fact make hardware and software obstacle against of nonoil export. Statistical population in this study is all superior exporters of non-oil material in Mazandaran province in 2014 with number of 30 people which all chose as sample.

Gathering data tool was structured questionnaire by researcher which has reliability and validation. Validity and reliability of research are dependent to concept that approved by supervisor professor, consultant and expertise. Reliability has determined by Cronbache's Alpha coefficient $\alpha=0 / 47$. Data analyzed in two grade of descriptive and inference by SPSS software.

Survival condition of companies depends on achieving to global markets and this necessity, needs high amount of attempt by companies. Iranian companies should welcome to customers around the world by challenging existence condition and behave them as partner by joint culture. Being as international company and work in competiveness market should be belief of Iranian companies and it does not happen except of educated human resource.
Private sector for presence in market has specific motivations and percept risk escalate and competition better than others. Against of governments which have high amount of money and national sources, private sector see itself stake of competition with others thereby more consider about its choice and is guarantee for successful present in global market.

One of the basic economic problems in Iran is investment, in private sector specially. For solving non-oil export dilemma there is not any way except of increasing production industrial products specially and increasing productivity. In 21st centuries which science and technology in industrial countries developed, cannot except export problems against of economic problems.

This research investigated non-oil export condition of Mazandaran province and for developing export identified its challenging factors. Findings of this research indicate there are problems in whole factors and subsets of non-oil export in Mazandaran province, therefore it is proportion that general managers of country, industrial owners, economists, businessmen, professors and university students endeavor for removal nonoil export obstacles and by making calm environment smooth export pass. Undoubtedly, knowing obstacles and problems of export intensify development targets and cause to permanent development.

Finally indicated target in this research seems that can provide appropriate field for perception complex of non-oil export of province. Meanwhile can use for officials, industrial owners and researchers as guidance plan for organizing different business.

\section{References}

1. Meon PG and Sekkat K. Does the quality of institutions limit the MENA's integration in the world economy? The World Economy. 2004;27(9):1475-1498. Doi: 10.1111/j.0378-5920.2004.00661.x

2. Moshirian F. Determinants of International Trade Flows in Travel and Passenger Services. The Economic Record. 2007;69(3):239-252. Doi: 10.1111/j.1475-4932.1993.tb02104.x

3. World Trade Organization. International Trade Statistics. 2012.

4. World Development Indicators Database. World Bank. 2011.

5. Homayounifar M and Rastegari F. Analysis of Economic-Political factors affecting Non-oil Export of Iran. American-Eurasian Journal of Agriculture and Environmental Science. 2008;2(1):16-173.

6. Barriers to Export Performance: an EmpiricalAnalysis of Small and Medium SizedCanadianExporters. Sheng Liang DengBrock University. Canada. 2014.

7. Western Cape Export Support Service.

8. Goldstein M and MS Khan. The supply and Demand for Export: A Simultaneous Approach. Review of Economics and Statistic. 1978;60(2):275-286. Doi: 10.1142/9789814749589_0002

9. Kazemzade L and AbouNoory AA. Supply and Demand functions estimated date of export to Iran, using a model system of simultaneous equation. Journal of agricultural Economics and development. 2006;54:124-103.

10.WNW Azman-Saini, Ahmad ZubaidiBaharumshah, Siong Hook Law. 
Foreign direct investment, economic freedom and economic growth: International evidence. Economic Modeling. 2010;27(5):1079-1089. Doi: 10.1016/j.econmod.2010.04.001

11. Mervar A. Estimates of the traditional Export and Import Demand Functions in the Case of Croatia. Croatian Economic Survey. 1993;79-93.

12. Mohammed Nur, Albert Wijeweera, Brian Dollery. Estimation of the Export Demand Function using Bilateral Trade Data: The Case of Bangladesh. South Asia Economic Journal. 2007;8(2):249-264.

13. Estimates the demand for import and export functions in the Iranian economy by using the Convergence ARDL. Journal of Economic.

14. Prasanna N. Impact of Foreign Direct Investment on Export Performance in India. J Soc Sci. 2010;24(1):65-71. Doi: 10.1080/09718923.2010.11892838

15.Seoul B. US trade preferences and export performance of developing countries: Evidence from the generalized system of preferences. International Business Review. 2006;15(1):68-83. Doi: 10.1016/j. ibusrev.2005.12.004

16.Vixon. Providing a model for the selection of project team using fuzzy approach. Journal of Modares. 2006;11(3).

17. Brans J P and Mareschal B. PROMETHEE methods. 2005.

18. Figueroa J, Greco S, Ehrgott M. Multiple Criteria Decision Analysis: State of the Art Surveys. Springer.

19. Harb, N. Oil Exports, Non-Oil GDP and Investment in the GCC Countries. Munich Personal Repec Archive (MPRA). 2008;15576.

20. Paul Krugman. "What should trade policy target", Strategic Trade Policy and New International Economics. MIT Press. 1980;69-88.

21. Akbar Kamijani, Seyyed Hussein, Mir Jalili. Strategic trade process for developing industrial export of Iran, Quarterly business journal. 2001.

22. Mustafa Ghazizade . Survey of success factors of Iranian Export Company in middle east market and performing strategy for developing. 2003.

23.Amin Nasseri et al. Macro architecture of tea in Iran and tea supply chain. custom business journal. 2011;119-143.

24.CathyMacharis, JohanSpringael, KlaasDe Brucker, AlainVerbeke.
PROMETHEE and AHP: The design of operational synergies in multicriteria analysis: Strengthening PROMETHEE with ideas of AHP. European Journal of Operational Research. 2004;153(2):307317. Doi: 10.1016/S0377-2217(03)00153-X

25. Mohsen Haghighi. Investigation on possibility of changing agricultural export yield of Khorasan and foreign marketing problems. M.A thesis, Tehran University.

26.Abou-Stait F. "Are Exports the Engine of Economic Growth? An Application of Cointegration and Causality Analysis for Egypt, 19772003". African Development Bank Economic Research Working Paper Series. 2005;

27. Rajapatirana S. Trade Policies, Macroeconomic Adjustment and Manufactured Exports: The Latin American Experience. Policy Research Working World Bank. 1996;132(3): 558-585.

28.Sheng Liang. Barriers to Export Performance: an Empirical Analysis of Small and Medium Sized CanadianExporters. DengBrock University. Canada.

29. Motevaseli. M, A Fathollah, M Tajal-Din, I. a comprehensive approach to strategic management. 13th (Ed.) Tehran: Publication of Toiled danesh. 2010.

30.Kazemi, M, Nazemi Shams al-Din, Ghavami A. Employing an integrated model for determining and prioritizing strategies for manufacturing companies using the Freeman and TOPSIS methods Case Study: Engineering and Construction Company Mapna generator (TDs), the eighth International Conference on Management. 2009;

31. Mazaheri A, Karbassian M, ShyruyehZad H. Identification and prioritization of risk in supply chain and manufacturing organizations using multi-criteria decision making, Management Conference, the first and second. 2011.

32.Khan M. Import and export demand in developing countries. IMF Staff papers. 1974;21(3): 678-693. Doi: 10.2307/3866553

33. Prince Y M, Hessel,s S J A, Verhoeven W H J. Factors Influencing Export Development of Dutch Manufactured Products, Business\& Policy Research. Zoetermeer. 2004. 